\title{
Bridging Two Solitudes - Integrating Literacy Research across Linguistic, Cultural and Disciplinary Boundaries
}

GAIL PRASAD

York University

SASKIA VAN VIEGEN

York University

Although there has been increasing interest and openness over the past two decades towards conducting interdisciplinary and collaborative language and literacy research, Anglophone and francophone scholarship in Canada have remained largely isolated within their respective linguistic communities. In 2014, both Anglophone and Francophone scholars came together for a pre-conference hosted at the annual meeting of Language and Literacy Researchers of Canada - L'Association canadienne de chercheurs en langue et litteratie (LLRC-ACCLL) on the theme of "Bridging (Two) Solitudes: Integrating Literacy Research across linguistic, cultural and disciplinary boundaries" in alignment with the broader theme of "Borders without Boundaries" at the Congress of the Humanities and Social Sciences. As applied linguistics and education researchers, we read this theme in relation to the historic divide between Canada's official languages, what Cummins (2008) has called a "two solitudes approach to bilingualism". Through this lens, two solitudes refers to the ways in which French and English have traditionally been conceptualized in curriculum for Canadian classrooms, compartmentalized as linguistic silos without engaging either language as a resource in the instruction of the other, and without acknowledging the legitimacy of and the potential for bi/multilingual language practice (ie. code-mixing, translanguaging) to enhance meaning making and communication in the educational context. Pedagogically, this approach disregards the extent to which students' linguistic resources are dynamically intertwined in cognitive processes and social activity; moreover, it overlooks the full range of students' linguistic repertoires, which may include not only official languages of English and/or French, but also minoritized languages such as Indigenous languages and immigrant languages. Within our field, the two solitudes metaphor has been used both as a critique and an invitation to consider the assumptions and theoretical bases of bilingualism guiding the work of educators, teacher educators and university-based researchers. For these reasons, we saw the conference theme as well-suited to bring together Francophone and Anglophone language and literacy research.

We purposefully organized the pre-conference to foster bilingual dialogue and to build bridges across theories, methodologies, and scholars themselves as a way of supporting future language and literacy research in Canada. To meet this goal required reflection upon our positionality at the time as two Anglophone doctoral candidate cochairs of the pre-conference, a desire for representation of linguistic diversity within our national association, and participation of both Anglophone and Francophone scholars in our pre-conference activities. Prior to this pre-conference, bilingual practices had not explicitly been a part of LLRC-ACCLL's mandate, nor had print or digital communications been disseminated in French. Importantly, 2014 marked the first year that Language and Literacy: A Canadian Education E-Journal (L\&L) published a French- 
language special issue, edited by the late Prof. Lizanne Lafontaine. Since then, L\&L has published a French-language special issue annually, and the association has adopted a bilingual name and created a bilingual website and communications materials (Lafontaine, 2015). Prof. Lafontaine's generous support during the bilingual preconference in 2014 and since has resulted in a consistent effort to employ Canada's two official languages in Language \& Literacy: a Canadian e-journal. As a result, LLRCACCLL has engaged a wider audience and provided more equitable opportunities for bilingual dialogue amongst language and literacy scholars across Canada.

Canadian language and literacy scholarship draws from a range of theoretical foundations and contexts which generate different explanatory and analytic lenses. Similarly, French-language and English-language scholarship tend to be rooted in different scholarly traditions and philosophies. These orientations point to the diverse epistemologies and ontologies that contribute to the breadth and depth of Canadian research. While this plurality holds potential for generative dialogue and inquiry among scholars working across these domains, such collaboration requires significant commitment on the part of researchers to both familiarize themselves with a broader range of scholarly literature and to foster relationships beyond linguistic, disciplinary and geographic boundaries (for some recent examples, see Cummins \& Early, 2011; Dezutter, Lamoureux, Thomas, Lau, \& Sabatier, 2017; Potvin et al., 2014).

The LLRC Pre-Conference sought to not simply to bridge these solitudes, but to create a space in which scholars working across a variety of contexts and diverse linguistic communities might engage one another. The day began with an opening keynote address delivered by Dr. Bronwen Low, McGill University. The title of Dr. Low's talk was Nous sommes ici/We are here: Building a pedagogy of listening in response to life stories of immigrants and refugees to Montreal. The closing plenary address was delivered by Dr. Diane Dagenais, Simon Fraser University. The title of Dr. Dagenais' talk was Beyond linguistic boundaries in literacy research. Overall, the day proceeded intentionally in such a way as to draw out participants' bilingual/plurilingual competence. For instance, keynote speakers presented in both English and French, moving seamlessly between languages without necessarily translating content in full. This practice signals the sociopolitical importance of bilingualism, and refuses the need to accommodate monolinguals in a bilingual interaction or setting through simultaneous or consecutive translation.

Despite these efforts to promote bilingualism, at times we were complicit in upholding the divide between the so-called "two solitudes". We held breakout groups for 'exquisite conversations' about participants' research, but organized these groups around English and French papers separately. This recognition raised practical questions, including: How do we promote bilingual dialogue about papers on a common theme if all authors are not bilingual themselves? Does this purposeful inclusion of articles in two languages make a journal bilingual? Whose voices still remain marginalized and how might we make space for a broader range of language and literacy practices to be taken up in Canadian research and in scholarly publication? These issues resonate with discussions in second language writing literature, wherein authors such as Canagarajah (2013) and Kubota (2014) have pointed out how the dominance of English and linguistic imperialism affects scholars and have questioned whether or not linguistic plurality can actually challenge publication practices. Indeed engaging with these issues on a deep 
level requires more than literal translation or simply including abstracts in both official languages; such an approach could be open to critiques similar to that of supporting multiliculturalism within a bilingual framework (Haque, 2012) or promoting neoliberal bilingualism (Heller, 2006). Borrowing from these critiques, we suggest that such efforts do not necessarily go far enough to reflect Canada's changing sociopolitical context or a dynamic, plurilingual approach to Canadian language and literacy scholarship.

In this special issue, we bring English and French articles together as an ongoing attempt to foster bilingual scholarly practices and showcase research developed across and responsive to the different linguistic and cultural traditions. We are mindful that the traditional linear and static form of an academic journal constrains creative, plurilingual, and dynamic research dissemination. However, working with this imperfect form, the three articles in this special issue explore different aspects of literacy development for linguistically, culturally and ability - diverse learners across English and French schools in Canada. They each highlight the complex communicative repertoires of children and youth in Canada, along with the ways in which teachers across different schooling contexts are working to support plurilingual development and practice.

In "Learning to read in multiple languages: A study exploring allophone students' reading development in French immersion," Bourgoin and Dicks report on a two-year study focusing on the reading development of allophone students transitioning into French Immersion in Grade 3. The authors highlight that allophone students learning French as an L3 are a heterogenous group who use a wide range of cognitive and metacognitive resources, including accessing L1 and L2 language literacy skills to support their L3 literacy practices. The authors highlight students' active cross-linguistic transfer as a key advantage for supporting their multilingual literacy expertise.

Dans la deuxieme article, Le Bouthillier et Kristmanson font l'analysent du développement des processus de l'écrit de quatre élèves à risques de la 7e année dans un programme d'immersion française. Cet recherche contribue aux savoirs sur une population souvent marginalisée dans la recherche sur les programmes d'immersion française. Grace à ces études de cas ethnographique, les auteurs demontrent comment les élèves à risques peuvent effectuer des progrès par rapport l'écrit.

Finally, in the third article, Doyle-Jones examines how elementary teachers plan their literacy curriculum and create learning opportunities for writing through multimodal resources and digital technology tools in their classrooms. Highlighting the challenges faced by educators in their efforts to animate multimodality in the classroom, the research documents principles of multimodal teaching in action. The teachers were capable of restyling their curriculum design and reworking their pedagogy to find new ways of teaching and learning that reflected a new literacies approach.

\section{References}

Canagarajah, A. S. (Ed.). (2013). Literacy as translingual practice: Between communities and classrooms. New York, NY: Routledge.

Cummins, J. (2008). Teaching for transfer: Challenging the two solitudes assumption in bilingual education. In Encyclopedia of language and education (pp. 1528-1538). Boston, MA: Springer.

Cummins, J., \& Early, M. (2011). Identity Texts: The Collaborative Creation of Power in Multilingual Schools. Staffordshire, UK: Trentham Books. 
Dezutter, O., Lamoureux, K., Thomas, L., Lau, S., \& Sabatier, C. (2017). Le rapport à l'écriture d'élèves de sixième année du primaire suivant un apprentissage intensif d'une langue seconde. Nouveaux Cahiers de la Recherche en Éducation, 20(2), 423.

Haque, E. (2012). Multiculturalism within a bilingual framework: Language, race, and belonging in Canada. Toronto, ON: University of Toronto Press.

Heller, M. (2006). Linguistic minorities and modernity: A sociolinguistic ethnography (2nd ed.). London, UK: Continuum.

Kubota, R. (2014). The multi/plural turn, postcolonial theory, and neoliberal multiculturalism: Complicities and implications for applied linguistics. Applied Linguistics, 37(4), 474-494.

Lafontaine, L. \& Dumais, C. (2015). Introduction des éditeurs numéro spécial francophone: L'oral en contexte scolaire et la littératie. Language and Literacy, 17(4), 28-51.

Potvin, M., Kugler, J., Borri-Anadon, C., Low, B., Larochelle-Audet, J., Stille, S., \& Stewart-Rose, L. (Eds.). (2014). Training and experience of professional educators in Ontario and Quebec [Special Issue]. Canadian Diversity, 11(2). Retrieved from https://www.elodil.umontreal.ca/fileadmin/documents/Articles_et_Documentation /Autres_references/Articles-Scientifiques/Diversite-canadienne-2015-171.pdf

Author Biography

Dr. Gail Prasad is an Assistant Professor with the Faculty of Education at York University. She completed her PhD in Languages and Literacies Education at the OISE / University of Toronto. Her research focuses on plurilingual development in children, youth and teachers. She has engaged in classroom-based research across elementary and secondary school settings using a range of creative and multimodal research methods to engage children and youth as co-ethnographers of their diverse language and literacies practices. Her work has been published in English and in French in journals such as the International Journal of Bilingualism and Bilingual Education, Language, Intercultural Education, TESOL Quarterly, Glottopol, and LIDIL: Revue de linguistique et de didactique des langues.

Dr. Saskia Van Viegen is an Assistant Professor in the Department of Languages, Literatures and Linguistics at York University. She earned a $\mathrm{PhD}$ in Curriculum, Teaching and Learning from OISE/ University of Toronto, and has seventeen years of experience as an English language instructor and program administrator. Her main research interest is language in education, particularly bilingualism, multilingualism and development of academic literacies. Her current projects explore language assessment in K-12 education, resources for learning in multilingual university settings, and language and literacy of youth refugees in secondary education. Publications from her recent work appear in several edited books and journals, including Canadian Modern Language Review, Language Assessment Quarterly, TESL Canada Journal, European Journal of Teacher Education, and TESOL Quarterly, and she recently co-edited (with Sunny Lau) the book Plurilingual Pedagogies: Critical and Creative Undertakings for Equitable Language (in) Education, to be published for the Springer Educational Linguistics series. 